A N N A L E S

UNIVERSITATIS MARIAE CURIE-SKŁODOWSKA

L U B L IN - P O L O N I A

VOL. LXI, 1

SECTIO G

2014

\title{
MAŁGORZATA STEFANIUK
}

\section{O potrzebie badań nad realnym aspektem prawa (na kanwie pracy G.L. Seidlera Rozważania o normie ustrojowej)}

On the Need to Investigate the Real Aspect of Law (Based on G.L. Seidler's Study Reflections on the Political Norm)

Praca Grzegorza Leopolda Seidlera Rozważania o normie ustrojowej ${ }^{1}$ została napisana (a przynajmniej ukończona) w Wałbrzychu w styczniu 1947 roku i w tym samym roku wydana w Krakowie przez Wydawnictwo Książnica. Od zakończenia wojny jej autor podjął pracę na Wydziale Prawa Uniwersytetu Jagiellońskiego, jednocześnie będąc wykładowcą Akademii Handlowej w Krakowie².

Tytuł omawianej pracy świadczy o tym, iż wpisuje się ona wyraźnie w zakres zainteresowań G.L. Seidlera, obejmujących problematykę prawa konstytucyjnego (jeszcze w 1938 roku ukazała się, napisana wspólnie ze Stanisławem Reymanem, Technika prac parlamentarnych ${ }^{3}$, zaś w 1948 roku praca pt. Władza ustawodawcza $i$ wykonawcza w polskich konstrukcjach ustrojowych 1917-19474). Rozważania ... różnią się jednak od wyżej wymienionych pozycji, gdyż w istocie mają one charakter metodologiczny. Stąd już sam tytuł może być odebrany jako nieco mylący, gdyż czytelnik zainteresowany problematyką norm ustrojowych (norm konstytucyjnych), którymi są normy zawarte w konstytucji, nie znajdzie w niej szczegółowych rozważań dających próbę odpowiedzi na pytanie, czym są tego

${ }^{1}$ G. L. Seidler, Rozważania o normie ustrojowej, Kraków 1947.

${ }^{2}$ A. Pieniążek, Grzegorz Leopold Seidler, [w:] Państwo. Prawo. Myśl prawnicza, pod red. A. Korobowicza, L. Leszczyńskiego, A. Pieniążka, M. Stefaniuka, Lublin 2003, s. 19; D. Minich, Władza państwowa w koncepcjach Grzegorza Leopolda Seidlera, Rzeszów 2013, s. 10. W 1975 roku Akademia Ekonomiczna w Krakowie przyznała prof. G.L. Seidlerowi doktorat honoris causa.

${ }^{3}$ G.L. Seidler, S. Reyman, Technika prac parlamentarnych, Biuro Prac Parlamentarnych Sejmu RP, Warszawa 1938.

${ }^{4}$ Idem, Wtadza ustawodawcza i wykonawcza w polskich konstrukcjach ustrojowych 1917-1947, Kraków 1948. Pracę tę ponownie wydano w Lublinie w 2000 roku nakładem Wydawnictwa UMCS. 
rodzaju normy, czy istnieją (a jeżeli tak, to jakie?) cechy charakterystyczne tych norm, pozwalające odróżnić je od innych norm systemu prawa, itp.

Rozważania ... są raczej diagnozą stanu nauki prawa konstytucyjnego, w zakresie badania norm konstytucyjnych, ale bardziej z punktu widzenia sposobu jej „uprawiania” niż z punktu widzenia uzyskanych rezultatów podjętych wysiłków badawczych. Należy przy tym zwrócić uwagę, iż lektura pracy skłania do wyciągania wniosków natury ogólniejszej, dotyczących całego prawoznawstwa, a nie wyłącznie jednej gałęzi prawa. Nie oznacza to jednak, że „norma ustrojowa” znalazła się w tytule przypadkowo, gdyż jest ona stałym punktem odniesienia, jak w zaproponowanym przez G.L. Seidlera kilkanaście lat później modelu badawczym wielopłaszczyznowej analizy prawa, w którym punktem odniesienia dla prawnika zawsze powinno być prawo, nawet jeżeli stwierdza on potrzebę poszerzenia badań na inne obszary.

Omawianą pracę, składającą się z sześciu rozdziałów, można podzielić na dwie wyraźnie rysujące się części: pierwsza część to diagnoza dotychczasowego sposobu uprawiania nauki prawa konstytucyjnego, druga to postulaty wyjścia prawa konstytucyjnego (a nawet całego prawoznawstwa) poza analizę obowiązującego prawa.

Z Rozważań... dają się wygenerować następujące wnioski. Po pierwsze, badania prowadzone przez dogmatyków prawa konstytucyjnego dokonywane są w kręgu konstrukcji myślowych i są ograniczane do przepisów oficjalnej konstytucji ${ }^{5}$. Są to badania materialne i badania formalne. Badania materialne dotyczą ustalenia treści zawartej w normach ustrojowych. Polegają one na: 1) systematycznym przedstawianiu treści przepisów obowiązującej konstytucji, co pozwala na zobrazowanie ustroju konkretnego państwa, jaki wynika z norm prawnych (bez uwzględnienia zjawisk realnych), 2) na ustaleniu pojęcia konstytucji, 3) na ustaleniu, jaką specyficzną treść powinny zawierać normy, aby można określić je jako normy ustrojowe, 4) na wskazaniu hierarchii ważności norm ustrojowych ${ }^{6}$. Badania formalne obejmują: 1) strukturę zdania wyrażającego normę ustrojową (zdaniem G.L. Seidlera nie są one prowadzone, gdyż norma ustrojowa w swojej budowie nie różni się od innych norm), 2) ustalenie elementów formalnych, wyróżniających normę ustrojową od pozostałych norm systemu prawnego, przy czym może to być wyróżnik lingwistyczny bądź specjalna procedura ich tworzenia lub uchylania ${ }^{7}$. Wskazane wyżej badania materialne i formalne, dokonywane wyłącznie w świecie konstrukcji myślowych za pomocą tradycyjnej, dogmatycznej metody, powodują, że dogmatyk „dobrze się tam czuje”, gdyż jest to świat „daleki i bezpieczny od niespodzianek, jakie gotować może krąg zjawisk realnych"».

\footnotetext{
${ }^{5} \mathrm{Na}$ temat typów badań naukowych zob. Idem, Rozważania..., s. 6.

${ }^{6}$ Ibidem, s. 19.

${ }^{7}$ Ibidem, s. 21-23.

${ }^{8}$ Ibidem, s. 28.
} 
Po drugie, postawa dogmatyka prawa ignorującego badania nad zjawiskami rzeczywistymi, a więc realnymi odpowiednikami norm prawnych, ma ,zgubny wpływ" na prawoznawstwo, w tym na naukę prawa konstytucyjnego9. G.L. Seidler stwierdza, iż sytuacja dogmatyka prawa konstytucyjnego jest jeszcze trudniejsza niż przedstawicieli pozostałych dyscyplin dogmatycznych z powodu silnego i wyraźnego, acz nieuwzględnianego przez nich nacisku życia na normy ustrojowe ${ }^{10}$. Wspomniany ,zgubny wpływ” jest spowodowany tym, że badania w ten sposób prowadzone mają charakter fragmentaryczny. Skoro norma prawna leży zarówno w kręgu myśli, jak i w kręgu realnym, to badania nie powinny być ograniczane wyłącznie do tego pierwszego kręgu. Dogmatyzm eliminuje badania nad przeżyciami prawnymi zarówno u jednostek, jak i w całym społeczeństwie. Co więcej, taka postawa ma również wpływ na sposób postrzegania prawników przez społeczeństwo. Nie jest przypadkiem, że Rozważania... poprzedza cytat z powieści Faraon Bolesława Prusa:, „Bo wy jesteście ludźmi, dla których otworzył się świat cegieł i papirusów, ale zamknął się ten prawdziwy, na którym wszyscy żyjemy" ${ }^{11}$. Wydaje się, iż G.L. Seidler kieruje te słowa do prawników zamkniętych wyłącznie w świecie norm obowiązującego prawa, niedostrzegających realnej rzeczywistości i w taki też sposób postrzeganych przez społeczeństwo. Stąd sformułowany przez G.L. Seidlera postulat przekroczenia muru oddzielającego świat norm od świata zjawisk realnych.

Po trzecie, przeprowadzona krytyczna analiza sposobu prowadzenia badań w nauce prawa konstytucyjnego (i całym prawoznawstwie) prowadzi do wniosku, iż istnieje poważna potrzeba poszerzania zakresu dotychczasowych badań podejmowanych przy stosowaniu tradycyjnej, dogmatycznej metody o metodę socjologiczną. Nie można zamykać oczu na zjawiska życia realnego, tyle że już w tym miejscu należy zaznaczyć, iż sprowadzają się one według G.L. Seidlera do przeżyć psychicznych ${ }^{12}$. Zdaje on sobie sprawę, iż powyższa propozycja może budzić zastrzeżenia dogmatyków prawa (nie wyłączając nawet samej nazwy tej metody jako metody socjologicznej) ze względu na: 1) nieokreślony przedmiot badań socjologicznych, 2) zachłanność wchłaniania przez socjologię coraz to nowych dziedzin, 3) wielość teorii socjologicznych, 4) brak zgody (nawet wśród samych socjologów), jakiego rodzaju jest to nauka, jakiego rodzaju są jej sądy naukowe ${ }^{13}$. Powyższe przyczyny powodują, że „dogmatyk łatwo rezygnuje z badań w kręgu realnym, zachowując pobłażliwość doświadczonego człowieka dla młodzieńczych wyczynów nowej dyscypliny"14.

\footnotetext{
${ }^{9}$ Ibidem, s. 11-12.

${ }^{10}$ Ibidem, s. 33.

${ }^{11}$ Ibidem, s. 5.

${ }^{12}$ Ibidem, s. 8.

${ }^{13}$ Ibidem, s. 29-31.

${ }^{14}$ Ibidem, s. 31.
} 
Po czwarte, wskazane wyżej wątpliwości zanikają, zdaniem G.L. Seidlera, jeżeli badacz przyjmie fundamenty metodologiczne zaproponowane przez Leona Petrażyckiego ${ }^{15}$. Powołanie się na teorię L. Petrażyckiego nie jest przypadkowe i stanowi wyraz widocznego i znaczącego wpływu (do czego się G.L. Seidler przyznawał), jakie na autora Rozważań... miało seminarium petrażycjańskie prowadzone na Uniwersytecie Jagiellońskim przez Jerzego Landego ${ }^{16}$. Wśród osób, które były zainteresowane naukową spuścizną, jaka pozostała po Leonie Petrażyckim, znaleźli się uczeni, którzy następnie wywarli znaczący wpływ na polską naukę prawa. Należeli do nich, obok G.L. Seidlera, m.in.: A. Podgórecki, Maria Borucka, K. Opałek, W. Lang, T. Łoś, J. Górecki, J. Wróblewski ${ }^{17}$.

Seidler w Rozważaniach ... odrzucił monizm metodologiczny współczesnego mu prawoznawstwa, nawołując do wyjścia poza badania dogmatyczne w kierunku realnego działania prawa. „Realność” ta w istocie miała przejawiać się w badaniu przeżyć psychicznych, tak jak tego chciał L. Petrażycki. Badania dogmatyczne nad konstytucją powinny zostać uzupełnione badaniami socjologicznymi, przeprowadzonymi jednak w ten sposób, aby konstytucja była punktem wyjścia i stałym układem odniesienia, co pozwoli w konsekwencji na ustalenie ewentualnych odchyleń między kręgiem myśli a kręgiem realnym.

Wspomniane badania socjologiczne miałyby polegać na ustaleniu: 1) stosunku między konstytucją a naczelnymi lub naczelnym organem w państwie, 2) stosunku między konstytucją a społeczeństwem.

Jeżeli chodzi o pierwsze z powyższych zadań, a więc ustalenie stosunku między konstytucją a naczelnymi lub naczelnym organem w państwie, to jego realizacja odbywa się za pomocą metody socjologiczno-statycznej. Polega ona na skonfrontowaniu skonstruowanych za pomocą norm konstytucyjnych (będących wzorami dla zjawisk realnych) idealnych schematów naczelnych organów państwa, z faktyczną działalnością rzeczywistych podmiotów podejmujących decyzje i wiążąco wyrażających wolę państwa ${ }^{18}$. Tego rodzaju badania określa G.L. Seidler jako metodę socjologiczno-statyczną, gdyż ewentualną rozbieżność między działaniami organów naczelnych a normami ustrojowymi można ustalić w ściśle określonym czasie. Przeprowadzone badania mogą prowadzić do następujących wniosków: 1) organy naczelne działają zgodnie z normami ustrojowymi, tzw. istotność, ustalenie woli państwa odbywa się zgodnie z konstytucją, 2) organy naczelne nie działają zgodnie z normami ustrojowymi, tzw. pozorność, która może polegać na przekraczaniu uprawnień bądź na niewypełnianiu nałożonych na te organy obowiązków. Pozorność może wystąpić w dwóch postaciach, jako: 1) pozorność wewnętrzna, gdy uprawnienia organów naczelnych ulegają

\footnotetext{
${ }^{15}$ Ibidem, s. 35.

${ }^{16}$ I. Wlazłowska, Profesora Seidlera poplatany żywot, Lublin 2009, s. 30.

${ }^{17}$ A. Podgórecki, Zarys socjologii prawa, Warszawa 1971, s. 54.

${ }^{18}$ G.L. Seidler, Rozważania ..., s. 38.
} 
przesunięciu w ten sposób, że odbywa się ono wyłącznie w obrębie organów przewidzianych konstytucją, 2) pozorność zewnętrzna, gdy w państwie istnieje ośrodek dyspozycyjny, kształtujący wolę państwa, mimo że nie jest on przewidziany przez konstytucję. Wówczas na decyzje organów naczelnych wpływają czynniki pozakonstytucyjne, np. grupy nacisku oddziałujące na decyzje rządu ${ }^{19}$.

Zadanie ustalenia stosunku między konstytucją a społeczeństwem (adresatami) odbywa się za pomocą metody socjologiczno-dynamicznej, przy czym G.L. Seidler wyraźnie podkreśla, że badania te opierają się na osiągnięciach Leona Petrażyckiego. Wspomniana metoda polega na badaniu przeżyć psychicznych i ustaleniu, czy poza realnym przeżyciem psychicznym, wywołanym oficjalną normą ustrojową, istnieją inne przeżycia psychiczne dotyczące tej samej materii, którą reguluje norma ustrojowa. W ten sposób można ustalić dwie zasadnicze ewentualności: 1) przypadek zgodności - konkretna norma ustrojowa wywołuje jedynie przeżycia psychiczne (poczucie uprawnienia i obowiązku) odpowiadające normie, przy czym przeżycia te zawierają w sobie wyobrażenia o obowiązywaniu konstytucji, 2) przypadek niezgodności, gdy obok przeżyć psychicznych wywołanych konkretną normą ustrojową istnieją inne przeżycia, dotyczące materii uregulowanej normą ustrojową. Norma ustrojowa regulująca pewne zagadnienia wywołuje przeżycie psychiczne, ale jednocześnie wywoływane jest inne, równoległe przeżycie intuicyjne (autonomiczne) odnośnie tego samego zagadnienia. Treść tych przeżyć będzie więc odmienna, gdyż inne będą przekonania o uprawnieniach i obowiązkach wynikające z przeżycia intuicyjnego, a inne z przeżyć wypływających z obowiązującej normy ustrojowej, wzmocnionej dodatkowo obawą sankcji ${ }^{20}$.

$\mathrm{Z}$ ustalenia kolizji między oficjalną normą ustrojową a intuicyjnymi przeżyciami należy według G.L. Seidlera wyciągnąć wnioski, a mianowicie dokonać wartościowania, ocenić i ustalić stosunek między oficjalną normą ustrojową a intuicyjną normą ustrojową. Powyższe wnioski mogą zostać wyprowadzone poprzez przyjęcie założeń ewolucjonizmu społecznego, zakładającego tworzenie się coraz wyższych typów ustrojów społecznych. Badacz ustala dwa alternatywne wypadki: 1) normy ustrojowe oficjalnie obowiązującej konstytucji wyrażają ideę postępu w stosunku do intuicyjnych przekonań ludzi, 2) przekonania intuicyjne w zakresie ustroju są wyrazem postępu wobec przestarzałych przepisów ustrojowych ${ }^{21}$.

Wracając do wniosków, jakie generują Rozważania ..., to - po piąte - zaletą poszerzenia badań nad konstytucją o krąg zjawisk realnych jest zdaniem G.L. Seidlera to, że 1) pozwalają one na konfrontację idealnych schematów z rzeczywistością, 2) stwarzają podstawy programu polityki dla całego ustawodawstwa - twórcy konstytucji otrzymują narzędzie przekształcania charakteru społeczeństwa, co stanowi nawiązanie do idei polityki prawa L. Petrażyckiego. Inaczej bo-

\footnotetext{
${ }^{19}$ Ibidem, s. 39-42.

${ }^{20}$ Ibidem, s. 41-47.

${ }^{21}$ Ibidem, s. 48-49.
} 
wiem będzie kształtowało się ustawodawstwo na tle liberalnej, a inaczej na zawierającej elementy socjalne konstytucji, 3) pozwala na realizowanie wychowawczej funkcji prawa, gdyż wielokrotne powtarzanie norm wywołuje w psychice człowieka dyspozycje do określonego zachowania ${ }^{22}$.

Przedstawienie najistotniejszych wniosków wypływających z pracy G.L. Seidlera Rozważania o normie ustrojowej pozwala na spojrzenie na zawarte w niej idee zarówno z perspektywy, jaką daje upływ czasu, jak też rozwój aktywności badawczej jej autora i innych uczonych, którzy podejmowali podobną problematykę.

Wyrażony w Rozważaniach... wpływ koncepcji Leona Petrażyckiego jako podstawy metody socjologicznej, w dalszej pracy badawczej G.L. Seidlera przybierał różne oblicza. Wydana w 1957 roku praca pt. Doktryny prawne imperiali$z m u^{23}$ zawierała krytyczne omówienie koncepcji Petrażyckiego z punktu widzenia stanowiska marksistowskiego, ale (jeżeli pominąc ideologiczną otoczkę) był to jednocześnie wyjątkowo jasny i przystępny wykład najważniejszych założeń psychologizmu.

Wydaje się jednak, że w miarę upływu czasu G.L. Seidler coraz bardziej doceniał Petrażyckiego, czego wyrazem było wydanie (z jego inicjatywy) w 1981 roku całego tomu (XXVIII) „Annales Uniwersitatis Mariae Curie-Skłodowska. Sectio G”, którego Seidler był redaktorem naczelnym, poświęconego Leonowi Petrażyckiemu z okazji pięćdziesiątej rocznicy jego śmierci. Przedmowę do powyższego tomu napisał Seidler, nazywając Petrażyckiego „,największym słowiańskim filozofem prawa XX wieku”24. Pisał też: „Nasza wiedza o kulturotwórczej roli prawa, o jego integrująco-wychowawczej funkcji nie będzie już nigdy ani powierzchowna, ani naiwna. Musiała stać się i głębszą, i poważniejszą, ponieważ był Leon Petrażycki”25.

Podejmując próbę odpowiedzi na narzucające się wręcz pytanie o dalsze losy zgłaszanych przez G.L. Seidlera, zawartych w Rozważaniach... postulatów, należy stwierdzić, iż podjęta tam problematyka nie tylko nie została „porzucona”, ale pojawiła się w rozwiniętej, w szczególności nieograniczającej się wyłącznie do prawa konstytucyjnego, postaci. Wyrażone tam idee nabrały charakteru bardziej ogólnego, o czym świadczą kolejne prace G.L. Seidlera, zwłaszcza artykuł $W$ poszukiwaniu systemu wszechstronnej analizy prawa $^{26}$ oraz praca $Z$ zagadnień filozofii prawa. Prawo i polityka ${ }^{27}$.

\footnotetext{
${ }^{22}$ Ibidem, s. 50-54.

${ }^{23}$ Idem, Doktryny prawne imperializmu, Warszawa 1957, s. 49-77.

${ }^{24}$ Idem, Przedmowa, „Annales UMCS. Sectio G” 1982, Vol. XXVIII, s. II.

${ }^{25}$ Ibidem.

${ }^{26}$ Idem, W poszukiwaniu systemu wszechstronnej analizy prawa, „Annales UMCS. Sectio G” 1967, Vol. XIV, s. 1-22. Tekst ten został następnie przedrukowany w pracy Z zagadnień filozofii prawa. Prawo i idee, t. 1, Lublin 1984 (korzystam z drugiej z wymienionych publikacji).

${ }^{27}$ Idem, Z zagadnień filozofii prawa. Prawo i polityka, t. 2, Lublin 1984.
} 
W artykule $W$ poszukiwaniu systemu wszechstronnej analizy prawa wyraźnie została wyartykułowana koncepcja zakładająca rozszerzenie badań na prawem, gdyż tylko w ten sposób możliwe jest wszechstronne poznanie tego złożonego zjawiska społecznego. Wspomniane wyżej poszerzenie powinno zdaniem G.L. Seidlera obejmować: 1) badanie związków między normą prawną a świadomością ludzi podlegających prawu (od strony motywacyjnej - pobudek, dla których ludzie podporządkowują się prawu, jak też z punktu widzenia następstw wywoływanych w świadomości ludzkiej w wyniku stosowania prawa), 2) badanie związków między określoną sytuacją polityczną a powstaniem normy prawnej ${ }^{28}$.

Stąd potrzeba wszechstronnej analizy prawa obejmującej badanie prawa w ramach czterech faz. W pierwszej fazie - decyzji politycznej, należy badać, jakie są cele suwerena i organów prawotwórczych oraz sytuację społeczną leżącą u podłoża tworzenia określonej treści norm prawnych. Faza druga obejmuje badania w płaszczyźnie jurydycznej, obejmujące wykładnię i komentowanie norm, tworzenie pojęć i konstrukcji prawnych oraz opracowywanie systemów prawa. Są to dociekania analityczno-krytyczne, czasami uzupełniane studiami porównawczymi.

Dla niniejszych rozważań szczególne znaczenie mają dwie kolejne fazy: prawno-psychologiczna oraz socjologiczna. Badania w płaszczyźnie prawno-psychologicznej dotyczą motywów, jakimi kierują się obywatele, przestrzegając prawa, a więc ustalenia przyczyn wypełniania przez nich obowiązków. W tej fazie pole badawcze przesuwa się na teren psychologii, co powoduje, że mamy tutaj do czynienia z problematyką świadomości prawnej. Z kolei faza badań socjologicznych sprowadza się do stwierdzenia przemian w stosunkach społecznych w wyniku stosowania norm prawnych ${ }^{29}$. W tej płaszczyźnie mieszczą się dociekania nad skutecznością prawa, a bliżej dotyczą one: a) zagadnień dotyczących zachowania się organów władzy i obywateli w wyniku stosowania normy prawnej, b) ustalenia zasięgu zmian, które nastąpiły w dotychczasowych stosunkach społecznych pod wpływem stosowania normy prawnej (zmiany w środowisku wywołane normą), c) szukania odpowiedzi na pytanie, czy i w jakim stopniu obiektywna sytuacja, zmieniona pod wpływem normy, oddziałuje na tych, którzy wydali decyzję polityczną w postaci normy prawnej (zwrotne oddziaływanie prawa) ${ }^{30}$. W tej płaszczyźnie do socjologów powinno należeć wypracowanie metod badawczych, a do prawników wysuwanie problematyki dociekań. Prawnik powinien więc zajmować się pytaniem, „co badać?”, a socjolog ,jak badać?”31.

\footnotetext{
${ }^{28}$ Idem, Z zagadnień filozofii prawa. Prawo i polityka, t. 1, Lublin 1984, s. 18.

${ }^{29}$ Ibidem, s. 45-46.

${ }^{30}$ Ibidem, s. 46.

31 Ibidem, s. 50. Współcześnie można spotkać poglądy ze względu na zacieśniające się powiązania perspektywy socjologicznej i jurydycznej; prawnik i socjolog w jednej osobie może nie tylko stawiać pytania, ale również na nie odpowiadać. J. Zajadło, Socjologia prawa a filozofia prawa, [w:] Leksykon socjologii prawa, pod red. A. Kociołka-Pęksy, M. Stępnia, Warszawa 2013, s. 344.
} 
Zdaniem Lecha Dubela i Jarosława Kostrubca „Model badawczy prof. G.L. Seidlera, na który składały się w sumie cztery płaszczyzny badawcze, stanowił istotny wkład w określenie ram syntezy naukowej i kierunków badań empirycznych w prawoznawstwie. Intencją autora było stworzenie nie tylko solidnej podstawy dla badań zespołowych, ale także - a może przede wszystkim - «związanie jurysprudencji naprawdę z życiem»" ${ }^{\prime 32}$.

Porównując poglądy G.L. Seidlera dotyczące metod badania prawa, przedstawione $\mathrm{w}$ artykule $W$ poszukiwaniu systemu wszechstronnej analizy prawa, do tych wyrażonych wcześniej w Rozważaniach ..., można dostrzec pewne różnice, wynikające z pogłębienia wraz z upływem czasu naukowej refleksji na ten temat. Przede wszystkim w artykule z 1967 roku mowa jest nie tylko o metodzie socjologicznej (jak w Rozważaniach ...), ale również o metodzie prawno-psychologicznej. Zaproponowane w Rozważaniach ... badanie przeżyć prawnych (określane jako metoda socjologiczno-statyczna) w koncepcji wszechstronnej analizy prawa zostało przeniesione do badań w płaszczyźnie psychologicznej (zmiany w świadomości społeczeństwa w wyniku wydanej normy), zaś w fazie socjologicznej należało skupić się na badaniach skuteczności prawa. Należy jednak zauważyć, iż w literaturze przedmiotu kwestia możliwości rozdzielenia płaszczyzny psychologicznej od socjologicznej budziła poważne wątpliwości (jako „sztuczna”), stąd propozycja Z. Ziembińskiego, aby zaprzestać posługiwania się tymi określeniami i badać prawo w sferze realnej (pozajęzykowej) ${ }^{33}$.

Idee sformułowane przez Profesora G.L. Seidlera miały swoje konsekwencje praktyczne, co umożliwiła jego pozycja na Wydziale Prawa i Administracji UMCS w Lublinie i w Uniwersytecie. Pozwoliła ona na wcielenie ich w życie, czego najbardziej wymownym przykładem jest powstanie w 1980 roku istniejącego do dnia dzisiejszego Zakładu Socjologii Prawa.

Chociaż w Rozważaniach ... nie ma jeszcze w pełni sformułowanej koncepcji socjologii prawa, to w postulacie metody socjologicznej można odnaleźć pierwociny tej idei. $Z$ punktu widzenia współczesnego spojrzenia na miejsce socjologii prawa w naukach, gdzie jest ona traktowana jako: 1) nauka pomocnicza uzupełniająca badania dogmatyczne w poszczególnych działach prawa, 2) nauka odrębna (będąca częścią socjologii bądź jedną z nauk prawnych) - koncepcji G.L. Seidlera wynikającej z Rozważań... bliżej było do tej pierwszej wersji, zwłaszcza jeżeli weźmie się pod uwagę, że głoszone postulaty są związane z nauką prawa konstytucyjnego, a więc jedną z dogmatyk prawa. Wydaje się, iż w Zagadnieniach filozofii prawa. Prawo i polityka wersja socjologii prawa jako nauki pomocniczej prawoznawstwa jest w dalszym ciągu podtrzymana. Według Seidlera socjologia prawa jest „niczym więcej jak tylko zastosowaniem metod socjologicznych do

${ }^{32}$ L. Dubel, J. Kostrubiec, Ewolucja metodologii nauk prawnych w ujęciach Profesora Grzegorza Leopolda Seidlera, „Studia Iuridica Lublinensia” 2010, t. XIII, s. 23-24.

${ }^{33}$ Z. Ziembiński, Problemy podstawowe prawoznawstwa, Warszawa 1980, s. 93-95. 
zjawisk prawnych" ${ }^{34}$. W obrębie tej dyscypliny mieszczą się trzy grupy problemów: 1) powszechne wyobrażenia społeczeństwa o prawie i sprawiedliwości i stopień, w jakim są one zgodne z obowiązującym prawem, 2) poszukiwanie odpowiedzi na pytania o znajomość prawa: jaki jest jej poziom w społeczeństwie, jakie są sposoby informowania społeczeństwa o prawie? jak znajomość prawa wpływa na zachowanie obywateli i jaki jest zakres przestrzegania prawa? jakie czynniki ułatwiają, a jakie utrudniają przestrzeganie prawa, jak działają sankcje?, 3) zachowania aparatu władzy w procesie stosowania prawa ${ }^{35}$.

Podsumowując niniejsze rozważania, należy zauważyć, iż G.L. Seidler już u progu swojej aktywności naukowej dostrzegał potrzebę badań nad realnym aspektem prawa. Już w Rozważaniach o normie ustrojowej postulował wyjście poza metodę dogmatyczną i poszerzenie metod badawczych stosowanych w prawoznawstwie o metodę socjologiczną. Idei tej pozostał wierny w swoich dalszych pracach metodologicznych, przy czym wyraźnie zaznaczał, iż zwiększenie roli badań empirycznych w prawoznawstwie, a tym samym w socjologii prawa, nie odbywa się kosztem dociekań dogmatycznych czy dokonywanych poprzez teorię państwa i prawa. Szczególne znaczenie dla realizacji postulatów poszerzenia badań w prawoznawstwie miały odegrać osiągnięcia socjologii, o której pisał, iż w połowie XX wieku „wdarła się szerokim frontem do prawoznawstwa" ${ }^{36}$. W ten sposób myślenie analityczno-historyczne zostało zastąpione poprzez myślenie analityczno-funkcjonalne.

Analiza idei metodologicznych zgłaszanych przez G.L. Seidlera potwierdza, iż wiele głoszonych przez niego koncepcji było nowatorskich, a ich autora, bez nadmiernej przesady, można określić jako wizjonera.

\section{SUMMARY}

From the beginning of his research work Professor Grzegorz Leopold Seidler emphasized the need to study the real aspect of law. The starting point for a lawyer should always be the law, but in his/her studies s/he should not be content with the dogmatic method but should go beyond the circle of thought by using the sociological method. These ideas are contained already in one of the first studies by Professor G.L. Seidler Rozważania o normie ustrojowej (The Reflections on the Political Norm) and they are further developed in the next publications, in particular in the article $W$ poszukiwaniu systemu wszechstronnej analizy prawa (In Search of a System of In-Depth Analysis of Law). The two foregoing studies are methodological. They present conceptions that should without doubt be regarded as innovative ideas. The Reflections... permit conclusions not confined only to the way of practicing the science of constitutional law but also to jurisprudence as a whole, which should discern relationships between law and social reality.

${ }^{34}$ G.L. Seidler, Z zagadnień..., t. 2, s. 72. Odróżnienie socjologii prawa od innych nauk, opierające się wyłącznie na odmienności metody badawczej, nie jest już współcześnie uważane za wystarczające.

${ }^{35}$ Ibidem, s. 72.

${ }^{36}$ Ibidem, s. 66. 